\title{
Institutional obstacles to South African entrepreneurship
}

\author{
Fred Ahwireng-Obeng* \\ Graduate School of Business Administration, University of the Witwatersrand, P.O. Box 98, Wits, 2050 South Africa \\ Desmond Piaray \\ Formerly MBA student of the Graduate School of Business Administration, University of the Witwatersrand. P.O. Box 98, Wits; \\ 2050 South Africa
}

Received June 1999

\begin{abstract}
Institutional risk factors exert a powerful negative influence on entrepreneurial investment decisions in South Africa. This conclusion emerges from a study of South African manufacturing and service sectors based on a previous one conducted on a world-wide scale by the World Bank in 1997. The South African study examines six institutional variables by sector-type and market-access and finds that entrepreneurs of young, small and non-exporting firms particularly perceive these institutional obstacles as a real problem most of the time. This observation compares closely with the World Bank's report on subSaharan Africa. There are several implications for the finding. Despite far-reaching institutional reforms much more will be required if South Africa's transition to a democratic polity and open, liberal economy is to yield the widely-expected postapartheid dividends of rapid economic growth, high levels of employment and more equitable distribution of income and wealth. In the present circumstances, the country's prospective role as a growth-pole for Southern African regional development and the propelling force of an African renaissance is unlikely to materialise
\end{abstract}

* Author to whom correspondence should be addressed.

\section{Introduction}

If entrepreneurs' perception of institutional obstacles are taken to index their problems in dealing with the state, then by implication the South African business environment is largely inimical to attracting investment. The South African government has failed, so far, to minimise institutional uncertainty in its efforts to promote productive entrepreneurship on a large scale as a strategy for combating the country's foremost problems of unemployment and inequality. This shortcoming has severe, negative implications not only for the country's economic growth, but also for it assuming effective leadership of Southern Africa and sub-Saharan Africa.

One of the consequences of the recent global financial crisis is increasing sensitivity of investment to macro-economic instability and particularly to uncertainty and risk at the micro-economic level. For example, prospective investors have become more aversive to obstructive regulations, discriminatory taxation and disruptive government transition. Therefore, the views of entrepreneurs about the development, enforcement and reliability of laws, regulations and policies are critical inputs in investment decisions. In a world-wide study of this problem, a World Bank policy team interviewed 3800 private firms in 69 countries and developed five quantitative indicators of institutional uncertainty: predictability of rule-making; reliability of the judiciary; security of persons and property; political stability; and corruption. These measures were used to construct a composite indicator of institutional credibility which was found to be strongly correlated with investment (World Bank Policy and Research Bulletin, 1998).

The World Bank study has motivated this article with the core purposes of establishing, in a much greater detail, the main institutional obstacles that hamper the domestic private sector, examining whether these obstacles differ by industry- type and market-access and comparing the South African stumbling blocks with those identified by the World Bank for sub-Saharan Africa and developed countries. The particular interest in South Africa is that the poor perception of the institutional climate has not been mitigated by strong evidence of a social dialogue to reconcile the contradictions of the transition from apartheid and protectionism to democracy and liberalisation.

The 1995 National Economic Development and Labour Council Act established an independent institution, Nedlac, as the government's response to providing a policy legitimisation platform representing business, labour, community and other non-governmental organisations as well as relevant government ministries. In this way, South Africa has opted for a highly institutionalised form of social-corporatist pacting against the tide of market-dominated approaches elsewhere in the world. This is an extensive state-society interaction in policy-making in which the state has little or no direct capacity for influencing or controlling the policies or actions of unions or business associations. The range of social pacts processed and implemented, so far, include: skill improvement legislation; industrial relations legislation setting out the parameters of industrial democracy rights; equity legislation to redress past discrimination; competition policy; sectoral collective bargaining jurisdictions; national codes of conduct, that is, sexual harassment, retrenchment, and others; occupational safety; and substantive wage and working conditions agreement. While these new societal values and norms provide principles and legitimacy to the new political will, the critical issue is whether they sufficiently promote an entrepreneurship-friendly working environment. This is pertinent because the strong antithetical tendencies underlying these principles create uncertainties and ambiguities that inhibit entrepreneurial action. For example, the search for social 
welfare objectives such as basic needs, access safety and social inclusion is often counter balanced by trade and macroeconomic policy objectives of liberalisation, competition, privatisation and rapid economic growth.

Therefore, to the extent that the competitive imperative is advanced beyond distributive norms, the consequences of institutional malfunctioning could be disastrous. On the other hand, excessive bureaucracy without the corresponding obligation to compliance could result in institutional sclerosis. Additionally, a pre-occupation with protectionism could lead to squelching of liberalisation. Consequently, anarchy would prevail if the search for moderating alternatives is not guided by the notion of the public interest. Unavoidably, the challenge facing the new South African government is to implement an intervention that institutes enforceable rules, regulations and policies with the aim of promoting a national interest that includes the vibrance of business enterprise. In this article the five indicators of institutional uncertainty developed by the World Bank are adapted to South African conditions and a sixth introduced to capture entrepreneurs' perceptions on issues of government - business interface.

The next section clarifies the concepts beneath the six institutional variables and explains how they impact on the entrepreneurship process. Section three describes the investigation procedure, the characteristics of responding firms and summarises the results of the survey. The results are interpreted in section four, section five concluding the article with a discussion of the implications of the result of the study.

\section{Conceptual background}

The six institutional variables

\section{Uncertainty of laws and policies}

The impact on investment decision of (un)certainty of government laws and policies is a central theme in the Theory of Principal and Agent. In this theory, if the investor is the agent and the government the principal, then investment decisions of the agent will depend on his expectations of private benefits derived from policy decisions and institutional support structures provided by the principal (Person \& Tabellini, 1990).

The irreversibility of capital investment, that is, the financial loss incurred when retracting capital-intensive investment decisions means that such decisions can be negatively influenced by perceptions of uncertainty about government's behaviour with regard to implementation and changes in rules and policies. The problems of uncertainty intensify in transitional economies like South Africa, as groups previously controlled or repressed re-enter the economy to press for new demands. In attempting to accommodate these usually conflicting demands political leaders find it difficult to maintain macro-economic stability (Persson \& Tabellini, 1990).

Quite often, small businesses are the worst victims as they tend to have less knowledge of and involvement in the drafting of new regulations (Brunetti, Kisunko \& Weder, 1997).

\section{Credibility of government policies}

When entrepreneurs hardly believe that government policy will persist because they perceive them as inconsistent with other policies, having unrealistic time frames or lacking appropriate delivery structures such policies are deemed not to be credible.

\section{Crime and security}

Crime in this study encompasses organised crime, whitecollar crime, crime involving firearms, gender violence and crime against children, violence associated with group or political conflict, vehicle theft and hijacking. Security is defined as the ability of government to protect individuals and property against crime and theft. High levels of crime and insecurity constrain private sector investment decisions because they increase the cost of doing business.

\section{Reliability of the judiciary}

Laws and policies are intended to inspire public trust and respect, and their enforcement requires an effective supporting institution such as the judiciary. Therefore, any inconsistencies by the judiciary in enforcing laws create public mistrust and diminish its respectability however well intended it is (World bank, 1997). Lack of enforcement discourages investment because entrepreneurs' right cannot be upheld. The World Bank studies on Malta, Pakistan and Ukraine concluded that the independence of the judiciary, its power to enforce rulings and effectiveness as an organisation were repeatedly compromised. Consequently, the judiciary was viewed as an obstacle to private sector investment decisions (World Bank, 1977).

The judiciary's responsibilities towards private sector development include: providing legal protection against the infringement of intellectual property rights - patent designs, trademarks and copyright; upholding government decisions on barriers to trade and government-regulated policies; enforcing contractual obligations between parties; administering company laws as set by the government for the purpose of tax collection; protecting investors, creditors and the public from the mismanagement of public companies; and implementing competition laws by regulating natural monopolies and shielding the public from the abuse of monopoly power.

\section{Bureaucratic corruption and red tape}

Bureaucratic corruption involves actions of government agents in manipulating laws and policies for their own gain. Bureaucratic red tape refers to problems relating to enforcing compliance with government regulations. Mbaku (1994) researched bureaucratic corruption in Africa and concluded that it is encouraged by massive government regulations. Entrepreneurs hold two contrasting views about bureaucratic corruption. Firstly, it is a predictable, normal transaction cost of doing business and is therefore not an obstacle. On the other hand, it significantly increases business costs in the form of bribery and time spent negotiating with officials about interpretations of laws and regulations. Both the cost of bribery and the opportunity cost of negotiation time are reflected in product pricing, making the product uncompetitive in the market place (Mbaku, 1994). 


\section{Government - business interface}

There is a wide range of areas where government and business interface in the course of business activity. The outcome of these interactions directly impact on business. Areas of interaction include:

- central bank control over commercial bank interest rate, thereby directly controlling domestic investment levels;

- central bank foreign exchange policy controlling capital flows;

- govemment discretionary mandate on tax rates over business;

- government provision of public services;

- privatisation of state enterprises;

- financial reform to improve access to finance; and

- government regulatory laws on the labour market.

\section{Institutional obstacles and the driving forces of the entrepreneurship process}

The potential for successful venture creation, growth and harvest is determined by the fit between the principal driving forces of the entrepreneurship process: the entrepreneur or the entrepreneurial team, opportunity recognition and the marshalling and controlling of resources (Timmons, 1994). The creative brilliance of the lead entrepreneur and the quality, maturity and depth of the entrepreneurial team significantly influence the success of a venture. However, high levels of uncertainty of laws and policies and other forms of institutional obstacles requiring fluid adaptive responses discourage initiative, weakens perseverance and resilience and confuses risk-reduction strategy. The sources of opportunity generation are: changing circumstances, inconsistencies, lags and leads, information gaps, asymmetries, signals and vacuums. Opportunity attractiveness lies in the probability that a product or service can be created to add value to its end-user. Most importantly, it must be rewarding with sustaining margins and profits. But under very chaotic and uncertain circumstances, the less skilful majority of entrepreneurs tend to miss constantly moving opportunity targets. Entrepreneurs usually prefer to maximise profits by using minimum resources and minimise risks by controlling these resources through renting, leasing or borrowing rather than owning them. These risk minimising options become limited with increased institutional uncertainties. Consequently, implementation of a business plan and the creation of value to entrepreneurial stakeholders - partners, employees, customers, suppliers and service providers - is restrained (Timmons, 1994).

\section{Empirical investigation}

This section describes the structure of the questionnaire, implementation of the survey and characteristics of responding firms. It also presents the methods of analysis and summarises the survey results.

\section{Structure of the questionnaire}

The questionnaire first asked for general characteristics of the firm, five of which were considered: size, age, type of ownership, type of industry sectors and internationalisation with respect to market access. A major part consisted of 18 multiple-choice questions divided into six categories of institutional obstacles. All questions aimed to identify the degree of (un)certainty created by state action and to differen. tiate between the various components of uncertainties.

\section{Uncertainty of laws and policies}

These questions sought to evaluate uncertainty created by the law-making process. By answering questions put from various perspectives respondents evaluated whether they coped with changes in laws and policies affecting their business and whether they were informed of or involved in policy decisions.

\section{Credibility of government policies}

These questions related to the ability of government to adhere to major policies and meet policy milestones, the consistency of policies and entrepreneurs' understanding of government policy objectives.

\section{Crime and security}

The two questions in this section focused on whether the entrepreneur had confidence in the ability of government authorities to protect his person and property.

\section{Reliability of the judiciary}

The questions here inquired into the independence and power of the judiciary (courts and judges) to enforce laws. It probed specifically if the reliability of the judiciary presented a problem for doing business.

\section{Bureaucratic corruption and red tape}

These questions related to the degree of corruption and whether corruption was considered a predictable transaction cost or a source of uncertainty. The problem posed by such questions was the reluctance to admit to paying bribes. Therefore, several other questions approached the topic rather indirectly. In addition, the section directly questioned whether uncertainties in dealing with the state had stifled investment projects and whether senior management spent considerable time dealing with the legal requirements of business.

\section{Government - business interface}

This section provided a list of 13 government-related issues with which the firm had been confronted and respondents were asked to evaluate the degree to which these issues created obstacles to business activity. An overall statement on the perception of government as either a 'helping hand' or an 'opponent' was asked. The questionnaire ended with an openended section that invited respondents to provide additional remarks on the relationship between the private sector and government or comment on the questionnaire in general.

\section{Implementation of the survey}

The survey was implemented between May and July 1998 and involved 800 firms affiliated to the Johannesburg Chamber of Commerce and Industry (JCCI). Since Johannesburg is the economic power-house of the Gauteng Province which generates about $40 \%$ of South Africa's gross domestic product, the original data base of 1600 firms from which the sample derived is fairly representative of the total population 
of all manufacturing and service organisations in the country. In stratifying the sample into the two industry-types and also by market-access it was expected that these categories might be influenced to varying extents by institutional obstacles (see Table 1).

Table 1 Sample stratification

\begin{tabular}{lccc}
\hline \multicolumn{4}{c}{ Market access } \\
\hline Industry type & Foreign \& local & Only local & Total \\
\hline Manufacturing & 125 & 125 & 250 \\
Service & 125 & 125 & 250 \\
\hline Total & 250 & 250 & 500 \\
\hline
\end{tabular}

The questionnaire was either mailed or hand delivered to the managing director, general manager or the owner of the firm, each of whom was likely to be involved in strategic planning and would normally consider the effect of institutional obstacles on the running of the business. Follow-up telephone reminders after 15 days contributed to an actual response rate of $46 \%$ - much higher than the average of $20 \%$ in the country.

\section{Characteristics of responding firms}

Table 2 presents the distribution of firms surveyed by size, age, ownership, industry and market access respectively. Almost a quarter $(22 \%)$ of firms were very small (less than 20 employees). Small-sized firms (20-200 employees) dominated the sample and only $16 \%$ were medium sized (more than 200 employees). Therefore, the sample was heavily skewed toward medium-size firms. In terms of age, the sample was dominated ( $74 \%$ ) by young companies (less than 10 years business). Limited liability companies constituted $60 \%$, the rest almost equally represented by sole

Table 2 Descriptive statistics

\begin{tabular}{lc}
\hline Characteristics & Description \\
\hline 1. Size (Numbered employees) & \\
$<20$ & $22 \%$ \\
$20-200$ & $16 \%$ \\
$>200$ & $62 \%$ \\
2. Age (Numbered years) & \\
$<10$ & $74 \%$ \\
$>10$ & $26 \%$ \\
3. Ownership & \\
Sole proprietorship & $17 \%$ \\
Partnership & $10 \%$ \\
Pty & $13 \%$ \\
Pty Limited & $60 \%$ \\
4. Industry Type & \\
Manufacturing & $43 \%$ \\
Service & $57 \%$ \\
5. Market Access & \\
Local Only & $44 \%$ \\
Local and Foreign & $56 \%$ \\
\hline
\end{tabular}

proprietorship (17\%), partnership $(10 \%)$ and public companies (13\%). Distribution by industry type was almost even $-43 \%$ for manufacturing and $57 \%$ for the service sector. Finally, the sample represented $50 \%$ distribution by market access for local only and $50 \%$ 'foreign and local'.

\section{Methods of analysis and summary of results}

A 6-point Likert scale was used to code frequency of responses. Since ordinal data are inappropriate for measuring means, correspondence analysis was used to rescale the data into interval form. For the total sample the means of the rescaled data in each statement were calculated and ranked in order of importance. To determine the extent to which institutional obstacles differed by industry and market access, t-tests were conducted at $5 \%$ level of significance. Any significant differences indicate that the different groups perceived the statement differently. These techniques differ from those used in the World Bank survey. Therefore, to facilitate comparison, our results were reformatted to reflect average responses.

Tables 3 and 4 summarise the results. The majority of entrepreneurs believed that theft and crime represented serious problems that increased the cost of doing business and that this was the most serious obstacle. In addition, they felt that government authorities did not protect their person and property. They strongly agreed that government was not a 'helping hand'. This is confirmed by the overwhelming agreement that 11 out of the 13 policy issues in Table 4 were either 'always a problem' or frequently a problem. Crime and theft were the largest obstacles to entrepreneurial action followed in descending order of importance by tax laws and labour regulations. Corruption, policy instability, inflation as well as safety and environmental regulations were considered as 'mostly a problem'. Those considered as 'frequently a problem' were foreign currency regulations, inadequate infrastructure, financing and regulations on foreign trade. South African entrepreneurs have little trust in government policy. They 'strongly agreed' with all four statements relating to the credibility of government policy with a ranking order of 3 rd, 6th, 8th and 10th (Table 4). All these statements on uncertainty of laws and policies were perceived as problems in 'most cases' by respondents. Firstly, they felt that government failed to take account of their concerns voiced either directly or through their business associations. Secondly, they were uninformed of new laws and policies affecting their business and finally they regularly had to cope with changes in these laws and regulations.

The results show also the reliability of the judiciary as a real obstacle for the following reasons: lack of independence; little power to enforce ruling; and inefficient as an institution. With regard to bureaucratic red tape, the responses show that entrepreneurs spent a large percentage of their time with government officials discussing changes and interpretation of laws and regulations and that they did not invest because of problems relating to complying with government regulations and red tape. All three statements describing the bureaucratic corruption variable however tended towards the neutral scale point. Respondents could not confirm whether they made additional payments to government agents to get things done, neither could they confirm that if additional payments were made, it ever resulted in improved service for them. Finally, it 
Table 3 Ranking of statements - in order of agreement

\begin{tabular}{|c|c|c|}
\hline Ranking & Statement & Total mean \\
\hline 1 & Theft and crime represent a serious problem that substantially increases the cost of doing business. & 1.29 \\
\hline 2 & I am confident that government authorities do not protect my person and my property from criminals. & 1.34 \\
\hline 3 & Government policy 'milestones' are not frequently met. & 2.01 \\
\hline 4 & All in all, for doing business I perceive that the government is not a 'helping hand'. & 2.27 \\
\hline 5 & $\begin{array}{l}\text { In case of important changes to laws or policies affecting my business operation, the government does not take into account concerns voiced } \\
\text { either by me or by my business association. }\end{array}$ & 2.38 \\
\hline 6 & Government policies are inconsistent. & 2.47 \\
\hline 7 & The judiciary (courts and judges) does not have independence, has little power to enforce rulings and is inefficient as an institution. & 2.59 \\
\hline 8 & Government does not adhere to major policy announcements. & 2.69 \\
\hline 9 & The process of developing new rules or policies is usually such that affected businesses are not informed. & 2.76 \\
\hline 10 & I do not understand the objectives of the individual government policies that affect my business. & 2.82 \\
\hline 12 & I regularly have to cope with unexpected changes in rules, laws or policies, which materially affect my business. & 3.01 \\
\hline 13 & I do not make investments because of problems relating to complying with government regulations and red tape. & 3.14 \\
\hline 14 & A large percentage of manager's time is spent on negotiations with officials about changes and interpretations of laws and regulations. & 3.15 \\
\hline 15 & It is common for companies in my line of business to make some irregular 'additional payments' to government agents to get things done. & 3.75 \\
\hline 16 & If a company pays the required 'additional payment' the service is usually delivered as agreed. & 3.89 \\
\hline 17 & If a government agent acts against the rules I can go to another official or to his superior and get correct treatment. & 4.39 \\
\hline
\end{tabular}

Table 4 Ranking of policy issues - in order of the extent of problems they present

\begin{tabular}{llc}
\hline Ranking & \multicolumn{1}{c}{ Issues } & Total mean \\
\hline 1 & Crime and theft & 1.38 \\
2 & Tax regulation and/or high taxes & 1.89 \\
3 & Labour regulations & 2.14 \\
4 & Corruption & 2.25 \\
5 & Policy instability & 2.52 \\
6 & Inflation & 2.54 \\
7 & Safety or environmental regulations & 2.78 \\
8 & Foreign currency regulations & 3.05 \\
9 & Inadequate infrastructure & 3.20 \\
10 & Financing & 3.25 \\
11 & Regulations on foreign trade (exp/imp) & 3.38 \\
12 & Regulations for starting businesses/new operation & 3.56 \\
13 & Price control & 3.98 \\
\hline
\end{tabular}

was unclear whether they ever reported bribery to superior government officials. Tables 5 to 7 summarise the results by industry and market access. Tables 5 and 6 show that only in statements 4,5 and 16 were there such significant differences, in all cases the manufacturing sector's response being stronger than the service sector's. There were, similarly, no significant difference by industry type (Table 7) except for statements 1 and 18. In all cases, firms that distributed their products locally provided stronger answers.

Table 8 compares institutional obstacles identified in this survey with those identified in the World Bank report. It shows that entrepreneurs in South Africa had the least confidence in their government's ability to protect them from crime and security, protect their person and property and generally provide a helpful hand. While $69 \%$ of entrepreneurs in developed countries gave their government much credibility, an equal percentage of South African entrepreneurs were most cynical. Again, an overwhelming percentage of South African entrepreneurs complained about uncertainty of government laws and policies and are matched $(51 \%)$ by those in sub-Saharan Africa in their view that government failed to take their concerns into account in the formation of policies. Also, South African respondents are similar to their sub-Saharan African counterparts in their lack of trust in their judiciary but differ significantly on the statement that they do not make investments because of problems relating to complying with government regulations.

South African respondents share their disapproval of this statement with developed countries and the rest of the world. Bureaucratic corruption appears uncommon in developed countries but exist to a large extent in both South Africa and sub-Saharan Africa. In a similar pattern South African entrepreneurs and their sub-Saharan Africa counterparts would not report a defaulting government agent but nearly $50 \%$ of those in the developed countries would. Bribery in the latter cases improved performance.

\section{Interpretation}

South Africa is currently drawn in a tide of schizophrenic development. It is an upper-middle income economy with a sophisticated banking sector among other first-world infrastructure; a modern industrial sector; modest debt ratios; advanced market deregulation and reform; and serves as a gateway to international trade with the rest of the continent. However, at the level of institutional efficiency, it is just another failing Third World African country. The transition to an open economy with an open political system has generated considerable policy risks. Government has passed controversial labour, patent and competition laws and imposed new taxes and levies to fund new jobs - all of which are 
Table 5 Table of means for statements $1-16 \& 18$ by industry type

\begin{tabular}{|c|c|c|c|}
\hline $\begin{array}{l}\text { Statement } \\
\text { number }\end{array}$ & Statement & $\begin{array}{l}\text { Manu- } \\
\text { facture }\end{array}$ & Service \\
\hline 1 & I regularly have to cope with unexpected changes in rules, laws or policies, which materially affect my business. & 3.03 & 2.99 \\
\hline 2 & The process of developing new rules or policies is usually such that affected businesses are not informed. & 2.76 & 2.76 \\
\hline 3 & $\begin{array}{l}\text { In case of important changes to laws or polices affecting my business operation, the government does not take into account con- } \\
\text { cerns voiced either by me or by my business association. }\end{array}$ & 2.27 & 2.49 \\
\hline 4 & Government does not adhere to major policy announcements. & 2.47 & 2.91 \\
\hline 5 & Government policies are inconsistent. & 2.26 & 2.67 \\
\hline 6 & Government policy 'milestones' are not frequently met. & 1.93 & 2.09 \\
\hline 7 & I do not understand the objectives of individual government policies that affect my business. & 2.86 & 2.77 \\
\hline 8 & Theft and crime represent a serious problem that substantially increases the cost of doing business. & 1.33 & 1.26 \\
\hline 9 & I am confident that government authorities do not protect my person and my property from criminals. & 1.34 & 1.35 \\
\hline 10 & Reliability of the judiciary (courts and judges) presents a major problem to my business operation. & 2.95 & 3.01 \\
\hline 11 & $\begin{array}{l}\text { The judiciary (courts and judges) does not have independence, has little power to enforce rulings and is inefficient as an } \\
\text { institution. }\end{array}$ & 2.40 & 2.78 \\
\hline 12 & $\begin{array}{l}\text { It is common for companies in my line of business to have some irregular 'additional payments' to government agents to get } \\
\text { things done. }\end{array}$ & 3.74 & 3.75 \\
\hline 13 & If a government agent acts against the rules I can go to another official or to his superior and get correct treatment. & 4.61 & 4.18 \\
\hline 14 & If a company pay the required 'additional payment' the service is usually delivered as agreed. & 3.98 & 3.80 \\
\hline 15 & $\begin{array}{l}\text { A large percentage of manager's time is spent on negotiations with officials about changes and interpretations of laws and } \\
\text { regulations. }\end{array}$ & 3.16 & 3.15 \\
\hline 16 & I do not make investments because of problems relating to complying with government regulations and red tape & 2.81 & 3.46 \\
\hline 17 & All in all, for doing business I perceive that the government is not a 'heiping hand'. & 2.23 & 2.32 \\
\hline
\end{tabular}

unfavourable to direct investment. Indeed, the economy has frequently experienced low levels of foreign reserves, weak trade performance, low savings rate, low productivity and poor growth which further evoke negative sentiment from both domestic and foreign investors. The evidence from this study is that institutional risks from crime and security, corruption, dysfunctional government and similar sources are formidable and pose a real challenge to the transition.

South African entrepreneurs view crime as a grave threat to the well-being of their business and country. Confidence in

Table 6 Table of means for issues (a-m) by industry type

\begin{tabular}{llcc}
\hline $\begin{array}{l}\text { Statement } \\
\text { number }\end{array}$ & \multicolumn{1}{c}{ Statement } & $\begin{array}{c}\text { Manu- } \\
\text { facture }\end{array}$ & Service \\
\hline l & Crime and theft & 1.36 & 1.4 \\
$\mathrm{~g}$ & Tax regulations and/or high taxes & 1.78 & 1.97 \\
$\mathrm{e}$ & Labour regulations & 2.19 & 2.09 \\
$\mathrm{~m}$ & Corruption & 2.34 & 2.17 \\
k & Inflation & 2.36 & 2.73 \\
i & Policy instability & 2.38 & 2.65 \\
j & Safety or environmental regulations & 2.80 & 2.76 \\
f & Foreign currency regulations & 3.21 & 2.88 \\
d & Financing & 3.30 & 3.20 \\
h & Inadequate infrastructure & 3.41 & 3.00 \\
c & Regulations on foreign trade export/import & 3.47 & 3.28 \\
a & Regulations for starting businesses and new & 3.48 & 3.64 \\
& operation & & \\
b & Price control & 4.06 & 3.90 \\
\hline
\end{tabular}

government's control over crime is declining and feelings of personal safety are diminishing. What is worse, as expectations of the severity of crime and insecurity increase, confidence in the ability of government to resolve the problem decrease. Entrepreneurs then tend to seek private means of security which further increases the cost of doing business. Tax rates and labour regulations are predictable as the second most restraining government-business interface variable after crime and security because South African corporate tax rates are among the highest in the world. The three labour laws that have been passed - the Labour Relations Act, the Employment Equity Act and the Basic Conditions of Employment Act - all add markedly to inflexibility of the labour market and the cost of doing business.

The overall lack of credibility of government policies and uncertainty of laws and policies are also a predictable feature of a transition and, it is not difficult to find reasons for such lapses as inconsistent policies, poor implementation and inability to meet policy milestones. Undeniably, the new government is inexperienced and is bound to make teething mistakes. The poor rating of the reliability of the judiciary may be attributed to its ineffectiveness in discouraging crime through heavy sentences and the absence of the death sentence in particular rather than its inability to dispense its duties on private-sector issues. This is understandable considering the overwhelming concern for crime and security. With regard to bureaucratic red tape as another major obstacle to entrepreneurship, it is uncertain whether government can be blamed. A credible explanation is that $84 \%$ of the sample are by international definition small businesses (less than 200 employees) and $74 \%$ less than 10 years old. Small and young firms are frequently either naive or uninterested in existing and new laws and regulations that affect them. 
Table 7 Table of means for statements $1-16 \& 18$ by market access

\begin{tabular}{|c|c|c|c|}
\hline $\begin{array}{l}\text { Statement } \\
\text { number }\end{array}$ & Statement & $\begin{array}{l}\text { Manu- } \\
\text { facture }\end{array}$ & Service \\
\hline 1 & I regularly have to cope with unexpected changes in rules, laws or policies, which materially affect my business. & 2.75 & 3.22 \\
\hline 2 & The process of developing new rules or policies is usually such that affected businesses are not informed. & 2.80 & 2.72 \\
\hline 3 & $\begin{array}{l}\text { In case of important changes to laws or polices affecting my business operation, the government does not take into account concerns } \\
\text { voiced either by me or by my business association. }\end{array}$ & 2.41 & 2.39 \\
\hline 4 & Government does not adhere to major policy announcements. & 2.71 & 2.73 \\
\hline 5 & Government policies are inconsistent. & 2.39 & 2.58 \\
\hline 6 & Government policy 'milestones' are not frequently met. & 1.97 & 2.06 \\
\hline 7 & I do not understand the objectives of individual government policies that affect my business. & 2.68 & 2.91 \\
\hline 8 & Theft and crime represent a serious problem that substantially increases the cost of doing business. & 1.22 & 1.34 \\
\hline 9 & I am confident that government authorities do not protect my person and my property from criminals. & 1.35 & 1.34 \\
\hline 10 & Reliability of the judiciary (courts and judges) presents a major problem to my business operation. & 3.07 & 2.91 \\
\hline 11 & The judiciary (courts and judges) does not have independence, has little power to enforce rulings and is inefficient as an institution. & 2.46 & 2.74 \\
\hline 12 & $\begin{array}{l}\text { It is common for companies in my line of business to have some irregular 'additional payments' to government agents to get things } \\
\text { done. }\end{array}$ & 3.54 & 3.90 \\
\hline 13 & If a government agent acts against the rules I can go to another official or to his superior and get correct treatment. & 4.50 & 4.26 \\
\hline 14 & If a company pay the required 'additional payment' the service is usually delivered as agreed. & 3.81 & 3.93 \\
\hline 15 & $\begin{array}{l}\text { A large percentage of manager's time is spent on negotiations with officials about changes and interpretations of laws and } \\
\text { regulations. }\end{array}$ & 2.90 & 3.35 \\
\hline 16 & I do not make investments because of problems relating to complying with govemment regulations and red tape. & 3.84 & 3.80 \\
\hline 17 & All in all, for doing business I perceive that the government is not a 'helping hand.' & 2.09 & 2.43 \\
\hline
\end{tabular}

The neutral response to the bureaucratic corruption variable is unexpected considering the large number of investigations into government irregularities reported in the daily press. One plausible explanation is that entrepreneurs accept it as a predictable cost of doing business rather than an obstacle. The significant differences in responses between service and manufacture to the credibility of government policies and bureaucratic red-tape variables are not altogether expected.

There appears to be no reason for the first but the second may be attributed to the relatively higher capital intensity of the manufacturing sector, the irreversibility of capital investment and hence its greater sensitivity to unfavourable government regulations. The significance in response differential to questions $I$ and 18 by market-access may be explained by the fact that unlike 'local only' firms which have no exit route to escape unfavourable local working conditions, their 'foreign and local' counterparts use exports as an escape route. Consequently, they do not feel the effects to the same degree. Finally, the striking similarity of South Africa to sub-Saharan Africa in the large percentages of entrepreneurs worried about issues of government - business interface, credibility of government policies, crime and security, uncertainty of law-making, unreliability of the judiciary and corruption - indicates the extent to which South Africa departs from a typical upper middle-income society.

\section{Conclusion and implications}

The South African entrepreneurial environment is marked by a combination of negative factors - a mix of institutional, political and economic problems at the domestic level, superimposed by regional political instability such as the war in the Congo and adverse international economic forces like the instability of emerging markets. Any category of these forces could alone spur negative sentiments in domestic and foreign investors based on their believed risk levels. But it is the convergence of all these forces that has provided a thick veil of unfavourable perception about South Africa. The institutional risk component is quite remarkably debilitating and reflects the complex difficulties of the country's transition.

Agency theory predicts that unless market incentives are compelling enough to overcome institutional obstacles, entrepreneurs will limit their investments to establishing branch offices for sales and marketing rather than commit themselves to expanding existing production units or establishing new ones. Significant institutional reforms have been made in South Africa. This study shows, however, that there is need for further reforms. As a system of dialogue and governance providing business, community and labour with an institutionalised voice, Nedlac must have learnt useful lessons during its early years of operation to improve future performance.

Crime activities having dominated the negative perception of entrepreneurs may themselves be classified as negative or unproductive entrepreneurship. Their expected increase means a relative shrinkage of productive entrepreneurship and a restraint on economic growth and employment generation. This scenario is as bad for the South A frican economy as other implications of the country's poor institutional milieu. First, reduced direct investment will diminish the country's role as the gateway to trade and investment in Africa. Second, the present conditions of economic power asymmetry in Southern A frica will not change but will perpetuate South Africa's political predominance in the region and this will impact poorly on the prospects for regional 
Table 8 Percentage of respondents that ticked three answers in agreement to statement and those that ticked three answers in disagreement

\begin{tabular}{|c|c|c|c|c|c|c|c|c|c|}
\hline \multirow[t]{2}{*}{ Ranking } & \multirow[t]{2}{*}{ Statement } & \multicolumn{2}{|c|}{ South Africa } & \multicolumn{3}{|c|}{ Sub-saharan Africa } & \multicolumn{2}{|c|}{ Developed countries } & \multirow{2}{*}{$\frac{\text { World }}{\text { Disagree }}$} \\
\hline & & Agree & Disagree & Agree & Disagree & Agree & Disagree & Agree & \\
\hline 1 & $\begin{array}{l}\text { Theft and crime represent a serious problem that substantially increases } \\
\text { the cost of doing business. }\end{array}$ & 99 & 1 & 78 & 19 & 55 & 43 & 76 & 23 \\
\hline 2 & $\begin{array}{l}\text { I am confident that government authorities do not protect my person and } \\
\text { my property from criminals }\end{array}$ & 100 & 0 & 81 & 17 & 51 & 47 & 73 & 25 \\
\hline 3 & Government policy 'milestones' are not frequently met. & 90 & 10 & 55 & 41 & 48 & 50 & 54 & 44 \\
\hline 4 & $\begin{array}{l}\text { All in all, for doing business I perceive that the government is not } \\
\text { 'helping hand" }\end{array}$ & 69 & 31 & 43 & 54 & 30 & 69 & 46 & 53 \\
\hline *5 & $\begin{array}{l}\text { In a case of important changes to laws or policies affecting my business } \\
\text { operation, the Government does not take into account concerns voiced } \\
\text { either by me or by my business association. }\end{array}$ & 80 & 20 & 0 & 0 & 0 & 0 & 0 & 0 \\
\hline *6 & Government policies are inconsistent. & 95 & 5 & 0 & 0 & 0 & 0 & 0 & 0 \\
\hline 7 & $\begin{array}{l}\text { The judiciary (courts and judges) does not have independence, has little } \\
\text { power to enforce rulings and is inefficient as an institution }\end{array}$ & 75 & 24 & 57 & 39 & 33 & 64 & 57 & 42 \\
\hline 8 & Government does not adhere to major policy announcements & 60 & 40 & 76 & 23 & 45 & 54 & 69 & 31 \\
\hline 9 & $\begin{array}{l}\text { The process of developing new rules or policies is usually such that } \\
\text { affected businesses are not informed. }\end{array}$ & 81 & 19 & 81 & 16 & 62 & 37 & 77 & 21 \\
\hline 10 & $\begin{array}{l}\text { I do not understand the objective of the individual government policies } \\
\text { that affect my business. }\end{array}$ & 73 & 27 & 72 & 25 & 41 & 58 & 67 & 31 \\
\hline •11 & $\begin{array}{l}\text { Reliability of the judiciary (courts and judges) presents a major problem } \\
\text { to my business operation. }\end{array}$ & 60 & 40 & 0 & 0 & 0 & 0 & 0 & 0 \\
\hline 12 & $\begin{array}{l}1 \text { regularly have to cope with unexpected changes in rules, laws and } \\
\text { policies, which materially affect my business. }\end{array}$ & 74 & 26 & 53 & 37 & 9 & 87 & 34 & 60 \\
\hline 13 & $\begin{array}{l}\text { I do not make investments because of problems relating to complying } \\
\text { with government regulations and red tape. }\end{array}$ & 64 & 36 & 36 & 64 & 35 & 65 & 39 & 61 \\
\hline 14 & $\begin{array}{l}\text { A large percentage of manager's time is spent on negotiations with } \\
\text { officials about changes and interpretations of laws and regulations. }\end{array}$ & 56 & 44 & 50 & 45 & 14 & 84 & 42 & 56 \\
\hline 15 & $\begin{array}{l}\text { It is common for companies in my line of business to make some } \\
\text { irregular 'additional payments' to government agents to get things done. }\end{array}$ & 30 & 70 & 28 & 67 & 45 & 44 & 34 & 62 \\
\hline 16 & $\begin{array}{l}\text { If a company pays the required 'additional payment' the service is } \\
\text { usually delivered as agreed. }\end{array}$ & 49 & 51 & 21 & 29 & 59 & 27 & 30 & 34 \\
\hline
\end{tabular}

integration. Third, a disintegrated regional economy will increase the influx of immigrants into South Africa and fuel social conflicts that may spill over state borders. All this leaves a bitter disappointment for the people of Southern Africa and Africa: the long- awaited, post-apartheid dividends may not be realised in the foreseeable future. Inevitably, any hope of an entrepreneurial revolution to kick-start a continental renaissance will depend, to a large extent, on a vastly improved institutional climate.

\section{References}

Bendixen, M. \& Sandler, M. 1994. Converting verbal scales to interval scales using correspondence analysis. Unpublished research report and Study Guide, Graduate School of Business Administration, Johannesburg

Brunetti, A.. Kisunko G. \& Weder, B. 1997. Credibility of rules and economic growth. Washington DC: World Bank,

Business Voice Magazine. 1998. Business's views on local government. SACOB News, Johannesburg.

Business Voice Magazine. 1998. What is boosting business confidence,

SACOB News, Johannesburg.

Cargill, J. \& Segal, S. 1997. Foreign direct investment, South

African investment report 1997. Johannesburg: BusinessMap SA.

Dixet, A.K. \& Pindyck. R.S. 1994. Investment under uncertainty. Princeton: Princeton University Press.

Douwes, Dekker. L. 1998. Social-shaping the political commitment of the new South Africa. Johannesburg: Wits Business School
Greenacre, M.J. 1989. Theory and applications of correspondence analysis. London: Academic Press.

Haggard, S. 1991. Inflation and stabilisation. In Meier, G.M. ed. Politics and policy making in developing countries. Ist ed. San Francisco: ICS Press.

Mbaku, J.M. 1994. Bureaucratic corruption and policy reform in Africa Washington DC: World Bank.

NAFCOC. 1995. Report on democratisation and growth of the South African e conomy: barriers to entry. Johannesburg.

NEDCOR. 1997. Nedcor ISS crime report index series. Johannesburg. NEDCOR. 1996. The NEDCOR project on crime, violence and investment: executive summary of the main report. Johannesburg.

Perkinson, D.H. \& Roemer M. 1991. Reforming economic systems in developing countries. 1st Ed. U.S.A., Harvard: Harvard University Press

Persson, T. \& Tabellini, G. 1990. Macroeconomic policy, credibility and politics. 1st Ed. New York: Harwood Academic Publishers.

Timmons. J.A. 1994. New venture creation: entrepreneurship for the 2/st century. 4th Ed. Boston, Mass.: Irwin McGraw-Hill, pp. 15-22.

Rodrik, D. 1994. Promises, promises: credible policy reform via signalling, Washington DC: World Bank.

Secretariat for Safety \& Security, May 1996. Summary document of the national crime prevention strategv. Johannesburg

Singh, A. 1994. Openness and the market friendly approach to development: learning the right lessons from development experience. Washington DC: World Bank.

World Bank 1996. Restoring arbitrary state action and corruption, World Development Report. New York: Oxford University Press. Chapter 6.

World Bank 1997. Focusing on the effectiveness of the state. World Development Report. New York: Oxford University Press, Chapter 2. 